\author{
(online) $=$ ISSN $2285-3642$ \\ ISSN-L = $2285-3642$ \\ Journal of Economic Development, Environment and People \\ Volume 2, Issue 3, 2013 \\ URL: $\underline{\text { http://jedep.spiruharet.ro }}$ \\ e-mail: office jedep@spiruharet.ro
}

\title{
Assessing the changes in drought conditions during summer in the Republic of Moldova based on RegCM simulations
}

\author{
Vera Potop ${ }^{1}$, Constanta Boroneant ${ }^{2}$, Mihaela Caian ${ }^{3}$ \\ ${ }^{1}$ Czech University of Life Sciences Prague, Czech Republic, \\ ${ }^{2}$ University Rovira I Virgili, Tortosa, Spain, \\ ${ }^{3}$ Rossby Centre, SMHI, Norrköping, Sweden,
}

\begin{abstract}
.
We assess the changes in drought conditions during summer in the Republic of Moldova based on the Standardized Precipitation Index (SPI) calculated from monthly precipitation data simulated by the regional climatic model RegCM3. The RegCM simulations were conducted at a horizontal resolution of $10 \mathrm{~km}$ in the framework of EU-FP6 project -CECILIA. The domain was centered over Romania at $46^{\circ} \mathrm{N}, 25^{\circ} \mathrm{E}$ and included the Republic of Moldova.
\end{abstract}

Keywords: drought, Standardized precipitation index, RegCM, climate change.

\section{JEL Codes: Q 54,}

\section{Introduction}

Drought is a recurring extreme climate event over land characterized by below-normal precipitation over a period of months to years. It is defined as a dry spell relative to its local normal condition. Drought is often classified into three types (Dai, 2011): (1) Meteorological drought which is a period of months to years with below-normal precipitation. It is often accompanied with above-normal temperatures, and precedes and causes other types of droughts. (2) Agricultural drought is a period with dry soils that results from below-average precipitation, intense but less frequent rain events, or above-normal evaporation, all of which lead to reduced crop production and plant growth. (3) Hydrological drought occurs when river stream flow and water storages in aquifers, lakes, or reservoirs fall below long-term mean levels. Hydrological drought develops more slowly because it involves stored water that is depleted but not replenished. Severe drought conditions can profoundly impact agriculture, water resources, tourism, ecosystems, and basic human welfare.

In the last two decades, drought was one of the greatest threats for farmers cultivating field crops in the Southern and Eastern Europe. In extreme cases, the effects of drought can lead to serious damages to agricultural sector. Drier conditions and increasing temperatures already observed in many regions of 


\author{
(online) = ISSN $2285-3642$ \\ ISSN-L = 2285-3642 \\ Journal of Economic Development, Environment and People \\ Volume 2, Issue 3, 2013 \\ URL: $\underline{\text { http://jedep.spiruharet.ro }}$ \\ e-mail: office jedep@spiruharet.ro
}

Eastern Europe could lead to lower agricultural production and crop variability may increase. The Republic of Moldova is among the eastern European countries affected by extreme drought.

The changes of temperature/precipitation ratio over the year shows that although Moldova's baseline climate only for the end of summer and the beginning of autumn were characterized as semiarid, it is likely that in the future there would be significantly longer and deeper dry spells. In particular, according to the results of six General Circulation Model experiments based on A2 and B2 SRES scenarios, Moldova will face warmer and wetter winters and hotter and drier summers and autumns. The projected annual decrease of precipitation in association with increase of temperature would likely stimulate strong humidity deficit inducing droughts (Corobov and Overcenco, 2007).

In previous studies (Potop and Soukup, 2009; Potop, 2011) we have extensively analyzed the spatial and temporal evolution of drought events in Republic of Moldova by comparing results from the most advanced drought indices (e.g. the SPI and SPEI), which take into account the role of antecedent conditions in quantifying drought severity. In the present study, the Standardized Precipitation Index (SPI), originally developed by McKee et al. (1993) was adopted to assess and project drought characteristics in the Republic of Moldova based on regional climate model (RegCM) simulations. It is well recognized that Global Circulation Models (GCMs) can reproduce reasonably well climate features on large scales (global and continental), but their accuracy decreases when proceeding from continental to regional and local scales because of the lack of resolution (Meehl et al., 2007). This is especially true for surface fields, such as precipitation and surface air temperature, which are critically affected by topography and land use. However, in many applications, particularly related to the assessment of climate-change impacts, the information on surface climate change at regional to local scale is fundamental.

One alternative to bridge the gap between the climate information provided by GCMs and that needed in impact studies is nesting of a fine scale limited area model (or Regional Climate Model, RCM) within the GCM. Such an approach have been used in the framework of the EU-project CECILIA (Central and Eastern Europe Climate Change Impact and Vulnerability Assessment). The regional climatic model ICTP_RegCM3 centered over Romania and including the Republic of Moldavia was run at a horizontal resolution of $10 \mathrm{~km}$, for the current climate (1961-1990) and under SRES A1B scenario for 2021-2050 and 2071-2100 periods. In this paper we use monthly precipitation data simulated by the ICTP_RegCM3 to asses changes in drought characteristics over the Republic of Moldova based on the Standardized Precipitation Index (SPI) (McKee et al., 1993, 1995) at time scale of 3, 6 and 12 months.

\title{
2. Data description
}

We used monthly temperature means and precipitation totals simulated with the Beta version of the regional climatic model ICTP_RegCM3 at a horizontal resolution of $10 \mathrm{~km}$. The ICTP_RegCM model was originally developed (Giorgi et al, 1993) and then augmented and used in various reference and scenario simulations (Giorgi et al., 1994a, 1994b; Pal et al., 2004). 


\author{
(online) $=$ ISSN $2285-3642$ \\ ISSN-L = $2285-3642$ \\ Journal of Economic Development, Environment and People \\ Volume 2, Issue 3, 2013 \\ URL: $\underline{\text { http://jedep.spiruharet.ro }}$ \\ e-mail: office jedep@spiruharet.ro
}

The RegCM simulations conducted in CECILIA-FP6 Project covered a domain $\left(41.016^{\circ} \mathrm{N}-50.175^{\circ} \mathrm{N}\right.$; $\left.14.095^{\circ} \mathrm{E}-36.192^{\circ} \mathrm{E}\right)$ centered over Romania $\left(46^{\circ} \mathrm{N}, 25^{\circ} \mathrm{E}\right)$ (Boroneant et al,2009; Boroneant et al,2011; Halenka,2010). For this study we selected a model domain centered over Republic of Moldova $\left(45.01^{\circ} \mathrm{N}\right.$ $49.01^{\circ} \mathrm{N} ; 26.52^{\circ} \mathrm{E}-30.48^{\circ} \mathrm{E}$ ) (Fig. 1). The simulations were driven by ERA40 double nested from $25 \mathrm{~km}$ RegCM run for the period 1961-1990 and by the ECHAM driven RegCM run at $25 \mathrm{~km}$ for the time slices 1961-1990 (control run) and 2021 -2050 and 2071-2100 (A1B scenario runs). The CRU TS2.10 land observation data set (http://www.cru.uea.ac.uk/cru/data/hrg/ cru ts 2.10) has been used to validate the RegCM temperature and precipitation simulations. The horizontal resolution of CRU TS2.10 precipitation data set is $0.5^{\circ}$ lat $\mathrm{x}$ $0.5^{\circ} \mathrm{on}$. The monthly temperature and precipitation simulations have been also validated against observations recorded at 15 meteorological stations of Moldova's State Hydrometeoro-logical Service (SHS). The validation period was 1961-1990.

To examine spatial drought variability, three agro-climatic regions were delineated. The resulting input dataset consists of four to six stations for each region, with altitudes ranging from 21 to $242 \mathrm{~m}$ a.s.l. (Fig. 1a). The agro-climatic regions reflect various physical-geographical conditions (relief, slope and elevation). Prior to model validation with station observation data, the quality control of observational dataset was made by SHS and the Institute of Geography, Academy of Sciences, Moldova.

\title{
3. Methods
}

First, we validate the model ability to simulate monthly temperature and precipitation over the Republic of Moldova domain. In this respect, we compare the annual cycle of temperature and precipitation based on RegCM simulations forced with ERA40 reanalysis data with the corresponding annual cycle calculated from CRU TS2.10 land observation data set and from observations at 15 representative stations from Republic of Moldova.

The annual cycles of temperature and precipitation were calculated in each grid point of data sets downscaled at station coordinates and then spatially averaged. The same rule was applied for the station series. The RegCM simulations (control and scenario runs) forced with the ECHAM GCM have been corrected against the systematic errors induced by the GCM. The bias correction has been calculated as a difference (ratio) between the temperature (precipitation) mean of the control run and the ERA40 run for the reference period 1961-1990 and then applied to each value of grid point time series. We used the distribution version of the SPI program available on $\mathrm{ftp}$ ://ulysses.atmos.colostate.edu which was adapted for looping over each grid point of the domain.

In the original algorithm used to compute the SPI, McKee et al. (1993) adjusted a Gama distribution function to the precipitation series. Later, other authors tested several distributions based on different timescales and concluded that in the Central Europe, the Gamma distribution is sufficiently flexible function to calculate the SPI on various timescales (Lloyd-Hughes and Saunders, 2002). However, for climatic areas 


\author{
(online) $=$ ISSN $2285-3642$ \\ ISSN-L = $2285-3642$ \\ Journal of Economic Development, Environment and People \\ Volume 2, Issue 3, 2013 \\ URL: $\underline{\text { http://jedep.spiruharet.ro }}$ \\ e-mail: office jedep@spiruharet.ro
}

with widely ranging precipitation variability like in the southern and southeastern Europe, the Pearson III distribution is suitable (e.g., Vicente-Serrano, 2006). SPI can be calculated for various timescales to monitor meteorological, agricultural and hydrological droughts with respect to severity, duration and extent. To ascertain variability of different type of droughts in the country, the SPI was calculated for short-term (1 to 2 months), medium-term ( 3 to 12 months) and long-term timescales (13 to 24 months). The SPI calculated for 1 to 2 months is mainly considered meteorological drought, for 3 to 12 months it can be considered as agricultural drought and for 13 to 24 months it is qualified as hydrological drought. In this study, a summer drought episode (JJA) was defined as a continuous period of SPI values less than -1.0 at least once during the episode. Values of -1.0 to -1.49 correspond to moderate droughts, -1.50 to -1.99 severe droughts and below -2.0 to extreme droughts. Similarly, values from 1.0 to 1.49 correspond to moderate wet, 1.50 to 1.99 corresponds to severe wet and values above 2.0 correspond to extreme wet conditions. Values from 0.99 to 0.99 are qualified as normal conditions.

a)

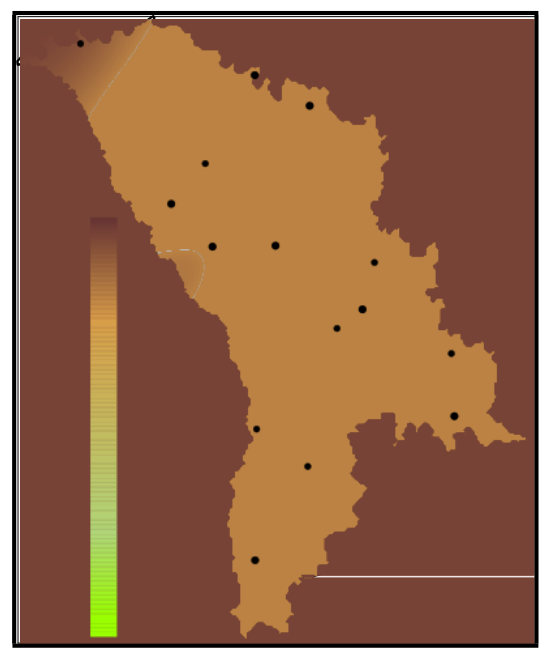

b)

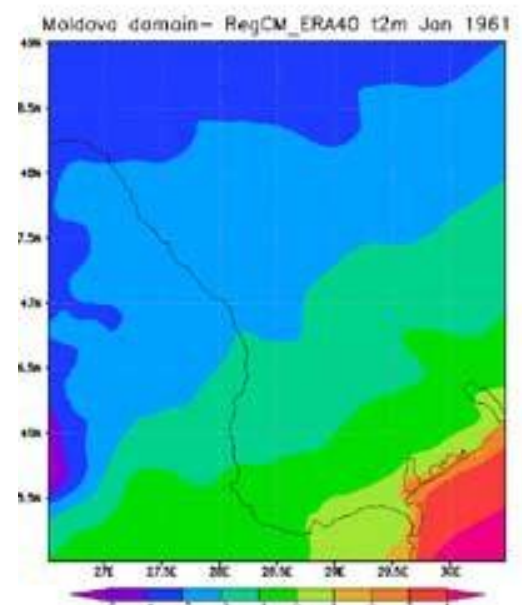

Fig. 1: Location of the 15 meteorological stations and RegCM Moldova domain $\backslash\left(26.5^{\circ}-30.5^{\circ} \mathrm{E} ; 45^{\circ}-49^{\circ} \mathrm{N}\right)(\mathrm{b})$

\title{
4. Results and discussion
}

\section{Validation model}

The model validation has been achieved at station level for the period 1961- 1990. In this respect, the gridded data of temperature and precipitation totals (RegCM simulations forced by ERA40 data and CRU observation data) have been downscaled to station coordinates. For these series, monthly means were calculated for the validation period. Then, these series of monthly means of RegCM simulations, CRU observations and station observations were spatially averaged and compared. The results are presented 


\author{
(online) $=$ ISSN $2285-3642$ \\ ISSN-L = 2285 - 3642 \\ Journal of Economic Development, Environment and People \\ Volume 2, Issue 3, 2013 \\ URL: http://jedep.spiruharet.ro \\ e-mail: office jedep@spiruharet.ro
}

in Figure 2. The model does well representing the annual cycle of temperature but slightly overestimates the winter (DJF) temperatures and slightly underestimates autumn (SON) temperatures (Fig. 2a). Precipitation totals are systematically overestimated by the model compared to stations and CRU data (Fig. $2 b)$. The largest magnitude of model precipitation errors are observed in late spring (AM) and summer months (JJA) when the model precipitation means are almost doubled the observed (station and CRU) precipitation means.

\title{
5. Changes in annual cycle of temperature and precipitation
}

The bias correction was applied to each value of the time series in each grid point of Moldova domain for RegCM control run and scenario runs forced with the ECHAM GCM. Then, the annual cycle of temperature and precipitation were calculated for each grid point of the domain and then spatially averaged and compared.

Fig. 3 shows the annual cycle of bias corrected temperature and precipitation totals calculated for 30 years, corresponding to the control run (1961-1990) and scenario runs (2021-2050 and 2071-2100), respectively. The results show that the projected temperatures for A1B scenario runs will increase in all months compared to the control run. The temperatures are projected to a higher increase by the end of the 21st century compared to the mid 21st century and reference period 1961-1990. The highest increase is expected during summer months (JJA). The precipitation totals are projected to slightly decrease in late autumn (ON), winter (DJF) and spring (MA) and increase in summer (JJA) during the period 2021-2050. Significant decrease is projected for summer (JJA) during the period 2071-2100.

(a)

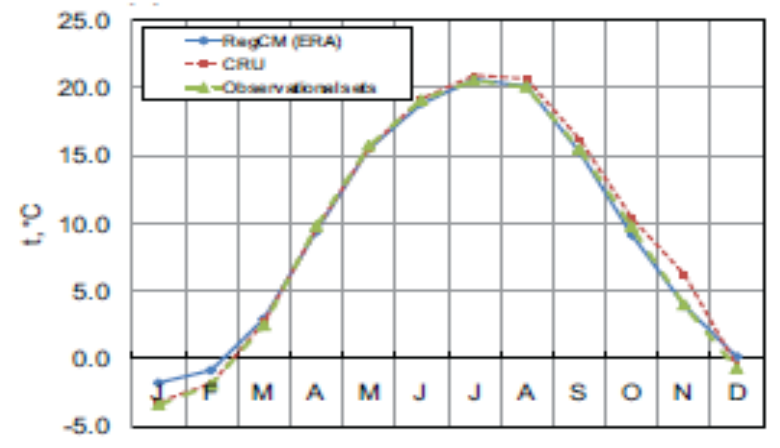

\section{(b)}

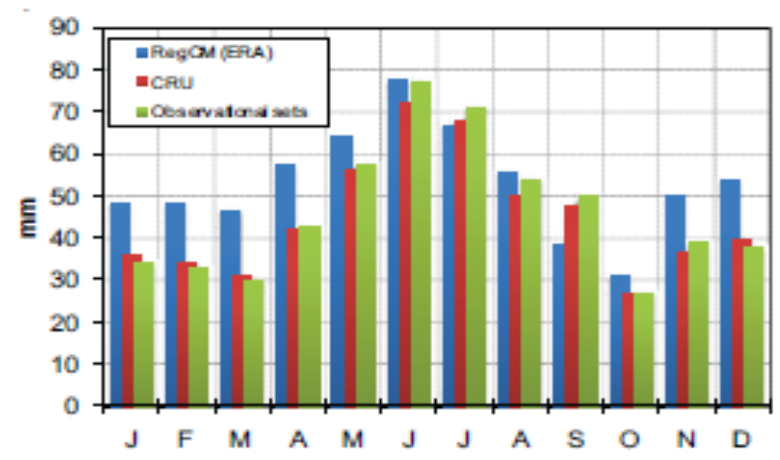

Fig.2: Annual air temperature (a) and precipitation (b) cycle for RegCM (ERA), CRU and observational datasets for reference period 1961-1990. 


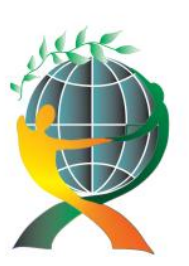

$$
\begin{gathered}
\text { (online) }=\text { ISSN } 2285-3642 \\
\text { ISSN-L = 2285 - } 3642
\end{gathered}
$$

Journal of Economic Development, Environment and People

Volume 2, Issue 3, 2013

URL: http://jedep.spiruharet.ro

e-mail: office jedep@spiruharet.ro
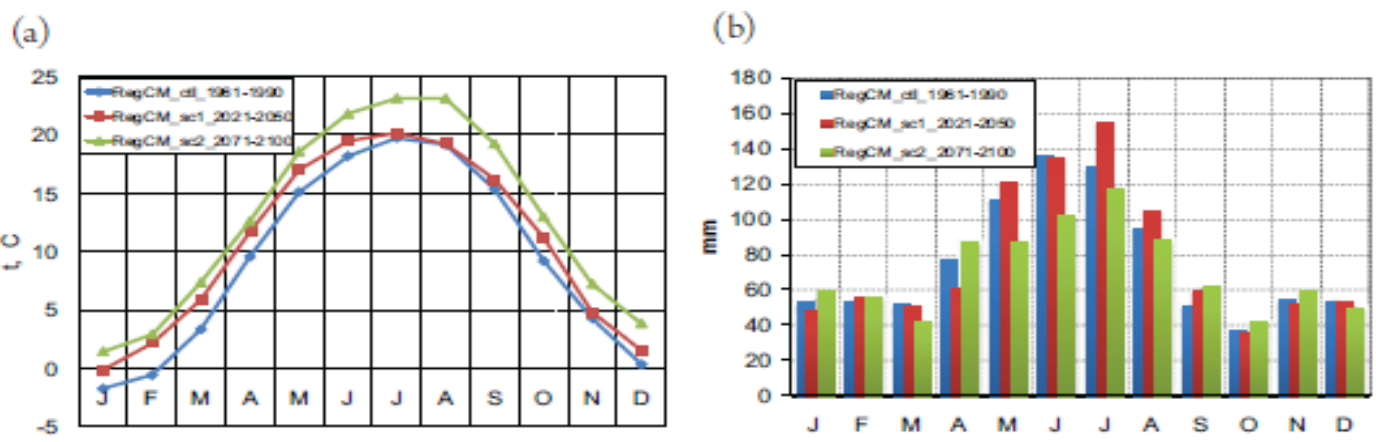

Fig.3: Annual air temperature (a) and precipitation (b) cycle after bias correction of the RegCM simulations for the time slices 1961-1990 (control run) and 2021 -2050 and 20712100 for Moldova domains.

\section{Observed spatio-temporal distribution of SPI values for the period 1960-1997}

For climate change projections of future drought characteristics in terms of SPI, an essential requirement is the SPI calculation of a reference climate. Analysis of the spatial and time evolution of drought based on SPI values calculated from observation data at 15 meteorological stations shows that drought conditions have noticeably increased in Republic of Moldova, with drought duration gaining in persistence during the last 20 years (Fig. 4). As a result, prolonged drought periods in the summer months during the early 1960s $(1961,1963,1967)$, middle 1970s (1973-1976) to early 1980s $(1981,1986-1987)$ and 1990s (1990, 1994, 1995, 1996, 1997) is observed. Fig. 4 also shows that wet summers have shortened their persistence and almost vanished after 1985. Additionally, the summer drought episodes have increased in frequency and intensity since the early 1980's. However, the longest extreme summer droughts were recorded during 1973-1976 and 1990-1997. In contrast, the extreme and moderate wet summers have been recorded in 1965, 1970 and 1985.

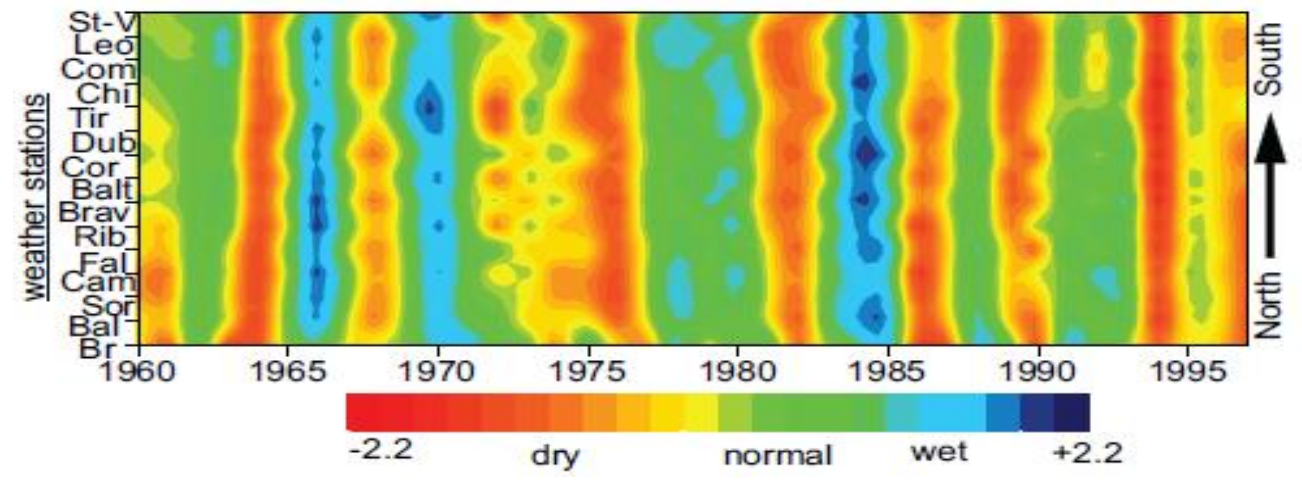

Fig. 4: Spatio-temporal distribution of SPI values at medium-term time scales (3 to 12 months) based on observations at 15 stations (1960-1997). 


\author{
(online) = ISSN $2285-3642$ \\ ISSN-L = 2285 - 3642 \\ Journal of Economic Development, Environment and People \\ Volume 2, Issue 3, 2013 \\ URL: http://jedep.spiruharet.ro \\ e-mail: office jedep@spiruharet.ro
}

In this study, a drought episode was defined as a continuous period of SPI values less than -1.0 at least once during the episode. We computed the consecutive number of months in each drought episode at time scales from 1 month to 24 months. Fig. 5a-b shows a summary of the mean number of summer drought episodes (a) and the average duration of drought (b) for each timescales from 1 month to 24 months per 3 agro-climatic regions for the period 1960 1997. At short timescales a high temporal frequency of drought episodes is showed. With increasing timescales, drought episodes appear with a lower temporal frequency and a longer duration. The mean number of summer drought episodes decreases with the increasing time scales. Thereby, the frequency of summer drought episodes decreases with the increasing length of time scales. As seen in Figure 5(a), the number of short-term summer drought events is significantly higher than those of long-term droughts. We also found that according to the summer medium-term drought (impacting agricultural production), all stations were affected by a severe or extreme drought spell during 1976, 1986, 1990 and 1994 years. Out of these, the drought episode of summer 1961 was recorded in the North agro-climatic region and some stations from Central region, but in the South region was not recorded.

Table 1 shows the mean number of summer drought years and average duration (in months) at shortterm, medium-term and long-term drought spells for 3 agro-climatic regions: Nord, Central and South (1960-1997). We should note that the mean number of summer drought years in short-term drought ranged from 14 to 15 for CRU dataset and from 16 to 15 for observational dataset (Table 1) while for the long-term time scale the number of drought episodes was decreasing until 7 years. Relatively similar results indicate both datasets at the short timescales when the average duration of summer drought was ranging between 0.9 and 2.9 months. At the mid-term time scale the average duration of drought were between 2.1 and 2.2 months for CRU data and observational stations, respectively.

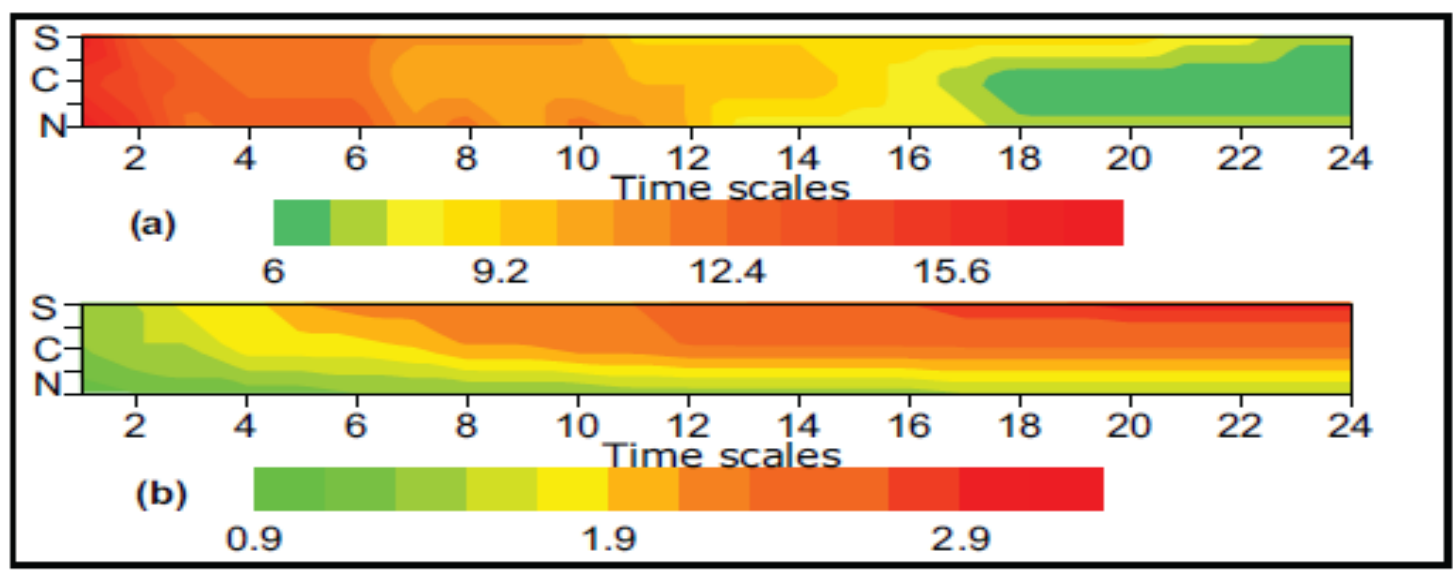

Fig. $5 a-b$ : The mean number of summer drought years (a) and average duration (in months) (b) at timescales from 1 month to 24 months for 3 agroclimatic regions: Nord (N), Central (C) and South

(S) (1960-1997) 


\author{
(online) $=$ ISSN $2285-3642$ \\ ISSN-L = 2285 - 3642 \\ Journal of Economic Development, Environment and People \\ Volume 2, Issue 3, 2013 \\ URL: http://jedep.spiruharet.ro \\ e-mail: office jedep@spiruharet.ro
}

Fig. 5a-b provides a summary for the average number and duration of summer drought episodes determined based on the SPI at short-, mid-, and long-term time spells.

Table 1: Number of years with summer drought and their average duration (in months) at short-term (1-2 months), medium-term ( 3 to 12 months) and long-term timescale (13 to 24 months) for 3 agroclimatic regions of Republic of Moldova: Nord, Central and South (1960 1997).

\begin{tabular}{c|c|c|c|c|c|c}
\hline \multirow{2}{*}{ Time scales } & \multicolumn{3}{|c|}{ CRU dataset } & \multicolumn{3}{c}{ Observational dataset } \\
\cline { 2 - 7 } & North & Central & South & North & Central & \multicolumn{1}{c}{ South } \\
\hline short-term & $14(0.9)$ & $13(1.2)$ & $15(1.2)$ & $16(1.1)$ & $15(1.4)$ & $15(1.4)$ \\
medium-term & $13(1.1)$ & $12(1.8)$ & $11(2.0)$ & $11(1.3)$ & $11(2.0)$ & $11(2.2)$ \\
long-term & $10(1.3)$ & $11(2.1)$ & $10(2.8)$ & $7(1.5)$ & $7(2.3)$ & $9(2.9)$ \\
\hline
\end{tabular}

Fig. 6 shows that in general, the southern region is more affected by droughts from moderate to extreme than the northern region. According to these results, extreme and severe summer drought occurred in 6 cases in the North and 10 cases in the Central and South regions based on CRU data and observational dataset at time scales of 3 and 6 months (Fig 6). The middle-term drought observed in the South agro-climatic region might be associated with less of precipitation. This result points out that this region is likely more vulnerable to drought. (Potop, 2011).

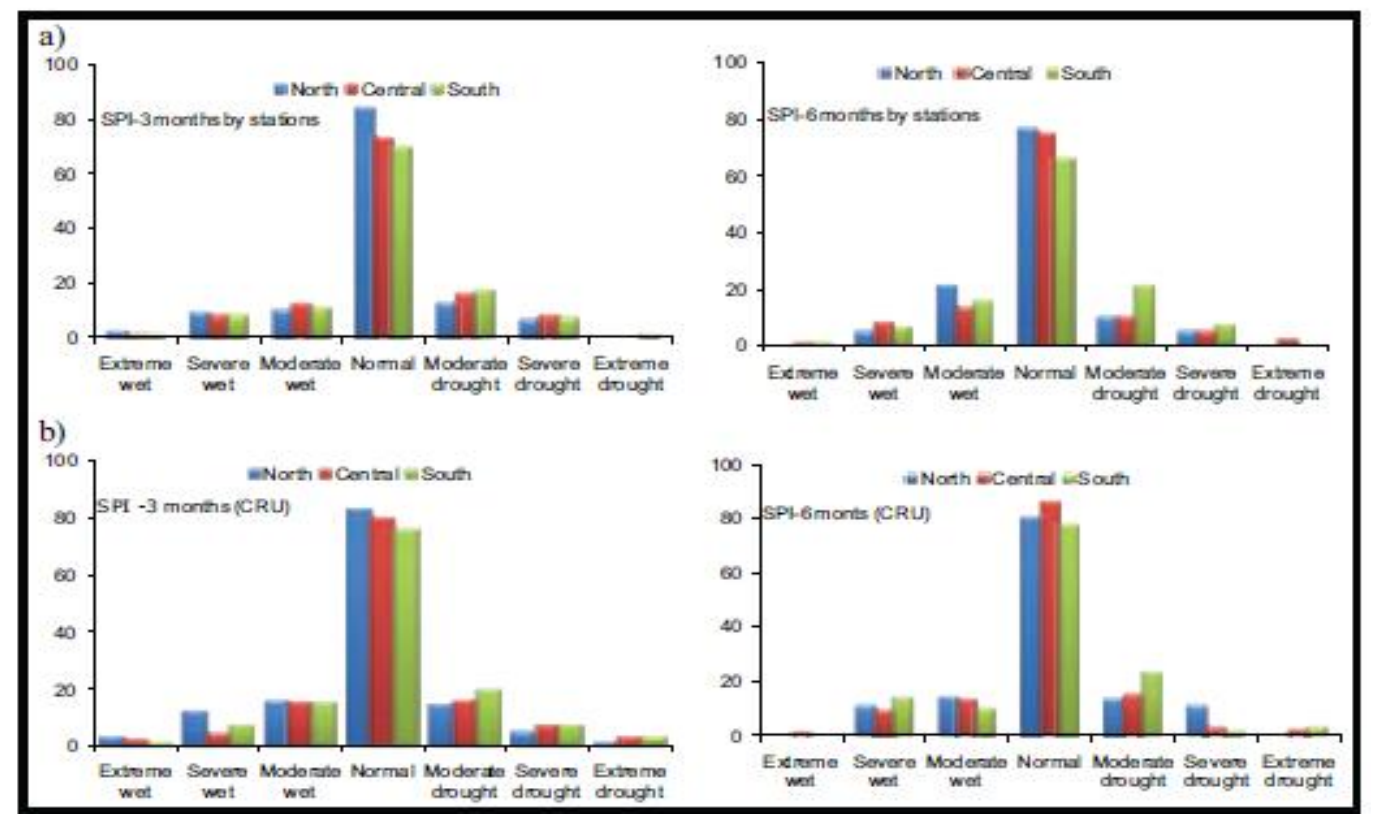

Fig. 6: Frequency distribution of the SPI values in 7 classes of drought category (number of cases) based on station observations a) and CRU data b) averaged per agro-climatic regions for the period 1960-1997 


\author{
(online) = ISSN $2285-3642$ \\ ISSN-L = $2285-3642$ \\ Journal of Economic Development, Environment and People \\ Volume 2, Issue 3, 2013 \\ URL: $\underline{\text { http://jedep.spiruharet.ro }}$ \\ e-mail: office jedep@spiruharet.ro
}

\title{
7. Projected changes in drought characteristics SPI - Temporal evolution
}

Drought appears first in the short time scales and if dry conditions persist, the drought develops at longer time scales. The use of several time scales of SPI take into account the role of antecedent conditions in quantifying drought severity, allowing a better understanding of time scales of water supplies. The SPI was calculated at time scales of 3, 6 and 12 months for each grid point of the RegCM both for the control and scenario runs. The temporal evolution of the averaged SPI calculated for 3, 6 and 12 months over Moldova's domain for the control run for the period 1961-1990 are represented in Fig. 7a). The evolution of the SPI calculated for 3 months shown in upper panel of Fig 7a) shows a high variability of the index between -1 and +1 . The persistence of drought conditions can be easily identified from the SPI at time scales of 6 and 12 months. As the time scale for calculation the SPI increases ( 6 and 12 months) the wet and dry conditions can be clearly identified as well as their persistence. The antecedent conditions in SPI calculated for 6 and 12 months point out on persistence of dry and wet conditions for time lengths of some years (central and bottom panel of Fig. 7a). These characteristics are also true for the temporal evolution of SPI calculated for the scenario runs for the periods 2021-2050 and 2071-2100, respectively (Fig. 7b and 7c) at time scales of 3, 6 and 12 months. In terms of intensity and persistence of dry and wet spells, Fig. 7b) shows that the first part of the period 2021-2050 is characterized by intense and persistent wet spells which are projected to be followed by some years with severe drought. The variability of SPI is projected to increase at the end of this period.

The temporal evolution of SPI for the period $2071-2010$ for 3, 6 and 12 months is presented in Fig. 7c. The time series are characterized by a higher variability and longer persistence of both wet and dry periods as compared with the control run and scenario run for the period 2021-2050.

The projected changes in summer drought characteristics based on the SPI calculated from RegCM simulations are presented in Table 2 . It should be noted that the projected changes are presented as absolute number of summer drought events and their cumulative values of $\mathrm{SPI}<1.0$ simulated by the RegCM for the time slices 1961-1990 (control run) and under SRES A1B scenario for 2021-2050 and 20712100 periods.

The largest number of drought events was projected at the end of 21th century (2071-2100) at timescale of SPI-3 and SPI- 6 months. For instance, for SPI-3 monthly series projected 5 (SPI-3sc1) and 15 (SPI-3sc2) number of drought events for 2021-2050 and 2071-2100 periods, respectively (Table 2). The RegCM simulation produced fewer drought events at timescales of 3 months during the period 2021-2150. Therefore, during the mid-century period (2021 2050) is projected to be less frequently dry events for almost all timescales of SPI series. By the end of the 21st century the projections suggest that long-duration droughts could thus become more important than it is observed during the present climate. Increases in drought severity (expressed by cumulative values of SPI in drought episodes) are also projected for the end of century. The consequences of drought impact on agriculture and environment systems would be severe 


$$
\begin{gathered}
\text { (online) }=\text { ISSN } 2285-3642 \\
\text { ISSN-L }=2285-3642
\end{gathered}
$$

Journal of Economic Development, Environment and People

Volume 2, Issue 3, 2013

URL: $\underline{\text { http://jedep.spiruharet.ro }}$

e-mail: office jedep@spiruharet.ro

in terms of progressive scarcity of surface water due to high demand of irrigation and of intensification of erosion and desertification processes. Summer drying may also be attributed to a combination of both increased temperature and potential evaporation not balanced by the changes in precipitation. The use of a precipitation-based index does not take into account the changes in evapotranspiration, which are likely given projected changes in temperature (Blenkinsop and Fowler, 2007).

Table 2: Number of summer drought cases and their cumulative values of SPI<-1.0 at timescales 3, 6 and 12 months simulated by the RegCM for the period 1961-1990 (control run) and 2021-2050 and 2071-2100

\begin{tabular}{|c|c|c|c|c|c|c|c|}
\hline \multirow[t]{2}{*}{ model } & \multirow[t]{2}{*}{ time slices } & \multicolumn{3}{|c|}{$\begin{array}{c}\text { Summer SPI value based on averages } \\
\text { summer precipitation totals }\end{array}$} & \multicolumn{3}{|c|}{ JJA SPI monthly value } \\
\hline & & SPI-3 & SPI-6 & SPI-12 & SPI-3 & SPI-6 & SPI-12 \\
\hline RegCM ctl & $1961-1990$ & $5(-8.0)$ & $5(-9.1)$ & $5(-8.1)$ & $10(-14.3)$ & $13(-18.2)$ & $9(-13.7)$ \\
\hline RegCM scl & $2021-2050$ & $4(-5.0)$ & $4(-6.1)$ & $5(-8.6)$ & $5(-7.9)$ & $6(-7.9)$ & $12(-16.1)$ \\
\hline RegCM sc2 & $2071-2100$ & $5(-7.7)$ & $6(-10.0)$ & $5(-10.4)$ & $15(-19.1)$ & $12(-17.8)$ & $10(-16.6)$ \\
\hline
\end{tabular}

(A1B scenario runs) averaged for all the grid points of the Moldova domain.

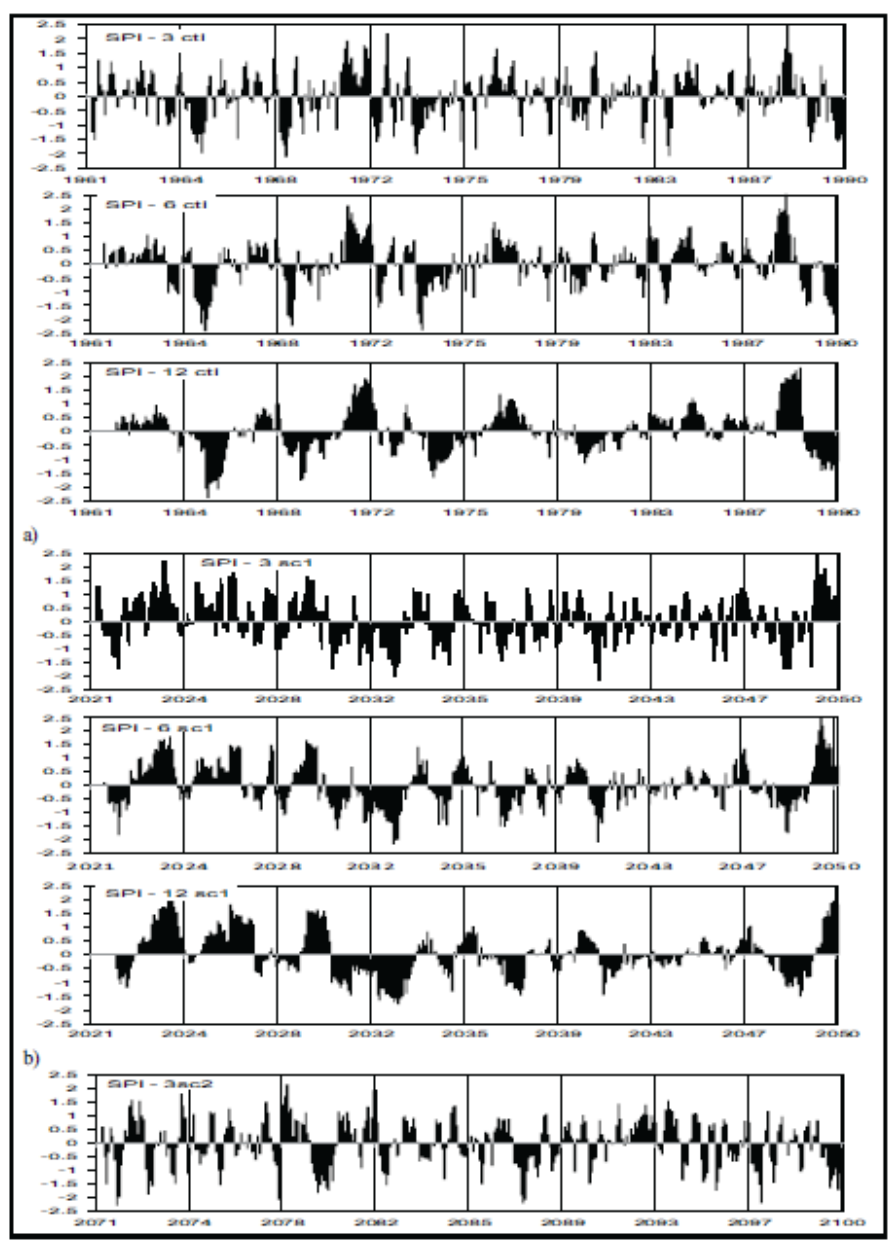




\author{
(online) $=$ ISSN $2285-3642$ \\ ISSN-L = $2285-3642$ \\ Journal of Economic Development, Environment and People \\ Volume 2, Issue 3, 2013 \\ URL: http://jedep.spiruharet.ro \\ e-mail: office jedep@spiruharet.ro
}

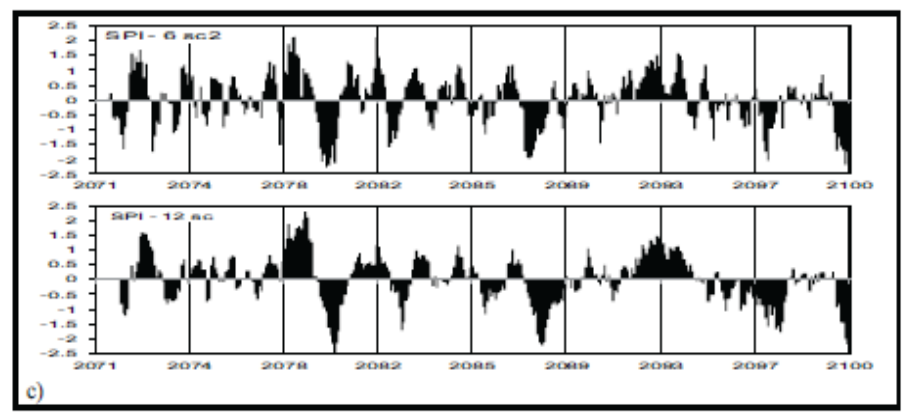

Fig. 7: SPI series at time scales of 3, 6 and 12 months based on monthly precipitation totals simulated by the RegCM control run a) (1961-1990) and A1B scenario runs b) (2021-2050) and c) (2071-2100), averaged for all grid points of the domain. SPI - Frequency distribution

Frequency distribution of monthly SPI values in 7 classes of drought category (\%) for the time slices 1961-1990 (control run) and 2021-2050 and 2071-2100 (A1B scenario runs) for 3, 6 and 12 months are represented in Fig. 8 a), b) and c), respectively.

Fig. 8 shows that there are not significant differences between frequency distribution of SPI values calculated for 3, 6 and 12 months in the control run and the two A1B scenario runs. The normal conditions represent $67 \%$ out of the total values of SPI in all grid point of the domain. Moderate drought and moderate wet are almost equally distributed around $9 \%$ while severe drought and severe wet are equally distribute around $5 \%$. Only slightly increase in extremely dry conditions $5 \%$ compared to extremely wet conditions $3 \%$ is observed both for the control and scenario runs.
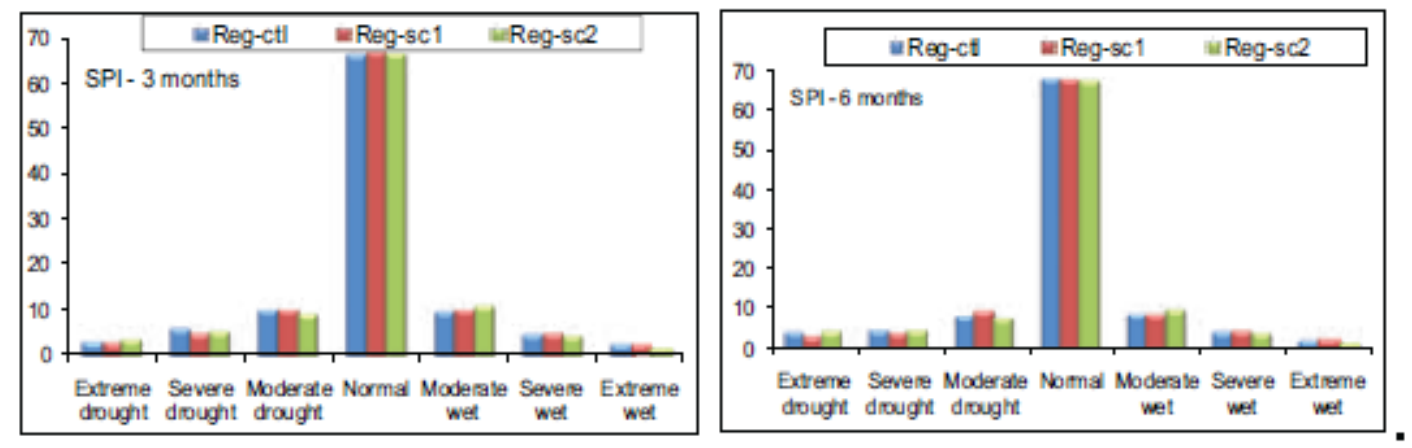


\author{
(online) $=$ ISSN $2285-3642$ \\ ISSN-L = $2285-3642$ \\ Journal of Economic Development, Environment and People \\ Volume 2, Issue 3, 2013 \\ URL: $\underline{\text { http://jedep.spiruharet.ro }}$ \\ e-mail: office jedep@spiruharet.ro
}

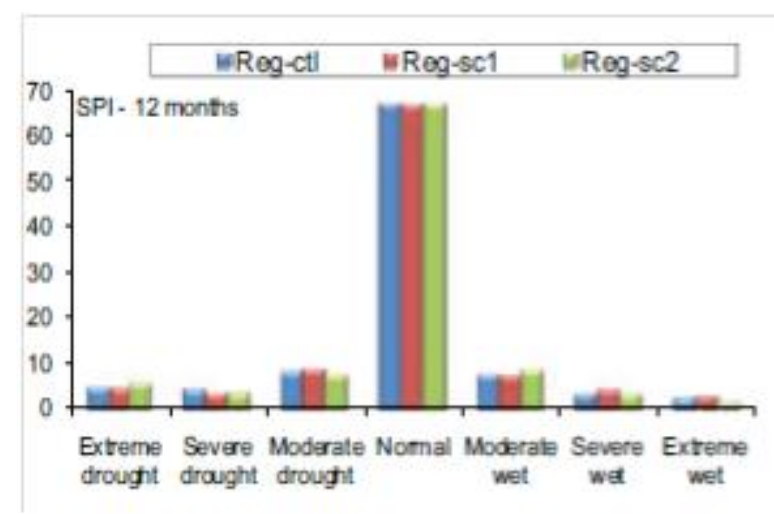

Fig. 8: Frequency distribution of monthly SPI values in 7 classes of drought category (\%) at time scales of 3,6, and 12 months calculated from RegCM simulations averaged over all grid points of the domain

\title{
8. Conclusions
}

Various economic sectors, notably agriculture, are sensitive to changes in the characteristics of drought episodes. This article presents the results of the first study on drought characteristics over Moldova based on SPI calculated for RegCM simulated data at high resolution (10 km) for the current (1961-1990) and two future climates (2021- 2050 and 2071-2100). The results can be summarized as follows:

1. RegCM simulations forced by ERA40 data were compared with station observations and CRU data downscaled at station coordinates. The results show that the model does quite well in representing the annual cycle of temperature but precipitation totals are systematically overestimated compared both to stations and CRU data. This feature is transferred to SPI which is based only on precipitation. Consequently, the model underestimates the severity of droughts.

2. The temperatures projected by the A1B scenario runs will increase compared to the control run. The temperatures are projected to increase by the end of the 21st century compared to the mid 21st century and to the reference period 1961-1990. The precipitation totals are projected to slightly decrease in autumn, winter and spring and increase in summer during the period 20212050. Significant decrease of precipitation is projected for summer during the period 2071-2100.

3. The evolution of the SPI series calculated for 3 months presents a high variability of the index around normal conditions. As the time scale for calculation the SPI increases ( 6 and 12 months) the wet and dry conditions can be better identified as well as their persistence.

4. Not significant differences between the frequency distribution of SPI values calculated for 3,6 and 12 months in the control run and the two A1B scenario runs have been identified. The normal conditions represent $67 \%$ out of the total values of SPI in all grid point of the domain.

5. The study represents the first steps in investigating the country vulnerability to drought in the context of climate change. However, more in-depth analysis is required to explore the vulnerability to drought of agro-climatic regions. 


\author{
(online) = ISSN $2285-3642$ \\ ISSN-L = 2285 - 3642 \\ Journal of Economic Development, Environment and People \\ Volume 2, Issue 3, 2013 \\ URL: $\underline{\text { http://jedep.spiruharet.ro }}$ \\ e-mail: office jedep@spiruharet.ro
}

\title{
9. Acknowledgements:
}

The research on drought conditions in the Republic of Moldova was supported by the Czech research project MSM 60460901; The RegCM simulations have been produced in the NMA-Romania in the framework of CECILIA-EU-FP6 Project, Contract 037005 GOCE/2006 (http://www.cecilia-eu.org).

\section{References}

[1] Blenkinsop S. and Fowler H. J. (2007) Changes in European drought characteristics projected by the PRUDENCE regional climate models. Int. J. Climatol.(27), 1595-1610.

[2] Boroneant C., Caian M., Vasile L., Cheval S., Ilie C. and Coll J. R. (2011) Summer drought analysis across Romania based on RegCM simulations. WCRP (GEWEX/CLIVAR) Workshop on Drought Predictability and Prediction in a Changing Climate: Assessing Current Capabilities, User Requirements and Research Priorities, 2-4 March, 2011, Barcelona, Spain.

[3] http://drought.wcrpclimate.org/workshop/posters/Boroneant.pdf

[4] Boroneant C., Caian M., Boberg F., Enculescu A. and Matei M. (2009) Weather Extremes in Romania Simulated With a High Resolution RegCM for Current and Future Climates. In: MOCA-09 Conference, Montreal, 19-29 July 2009.

[5] http://www.moca-09.org/e/documents/IAMAS2009Program15w.pdf

[6] Corobov R. and Overcenco A. (2007) Use of climate modeling outputs for regionalization of global climate projections. In: Problems of ecological monitoring and ecosystem modeling, Vol. XXI, St. Petersburg Gidrometeoizdat, Russian Federation, pp. 123-145

[7] Dai A. (2011) Drought under global warming: a review. Wiley Interdisciplinary Reviews: Climate Change, (2), 45-65. doi: 10.1002/wcc.81.

[8] Giorgi F., Marinucci M. R. and Bates G.T. (1993) Development of a second generation regional climate model (RegCM2). Part I: Boundary layer and radiative transfer processes. Mon. Wea. Rev.,(121), 2794-2813.

[9] Giorgi F, Bi X and Pal J. S. (2004a) Means, trends and interannual variability in a regional climate change experiment over Europe. Part I: present day climate (1961 -1990). Clim Dyn (22), 733-756.

[10] Giorgi $\mathrm{F}, \mathrm{Bi} X$ and Pal J. S. (2004b) Means, trends and interannual variability in a regional climate change experiment over Europe. Part II: future climate scenarios (2071 -2100). Clim Dyn (23), 839-858.

[11] Halenka T. (2010) Cecilia - EC FP6 Project on the Assessment of Climate Change Impacts in Central and Eastern Europe. Global Environmental Change: Challenges to Science and Society in Southeastern Europe, SpringerLink, 2010, Part 3, 125-137, DOI: 10.1007/978-90-481-8695-2_11.

[12] Lloyd-Hughes B. and Saunders M. A. (2002) A drought climatology for Europe. International Journal of Climatology, (22), 1571- 1592 . McKee T.B., Doesken N.J. and Kleist J. (1993) The relationship of drought frequency and duration to time scales. Preprints Eighth Conf on Applied Climatology Anaheim CA.

[13] Amer Meteor Soc, pp 179-184. McKee T.B., Doesken N.J. and Kleist J. (1995) Drought monitoring with multiple time scales.

[14] Proceedings of the Ninth Conference on Applied Climatology. Amer Meteor Soc Boston, pp 233-236.

[15] Meehl G. A., Stocker T. F., Collins W. D., Friedlingstein P., Gaye A. T., Gregory J. M., Kitch A., Knutti R., Murphy J. M., Noda A., Raper S. C. B., Watterson I. G., Weaver A. J. and Zhao Z-C. (2007) Global climate projections. In Climate Change 2007: The Physical Science Basis. Contribution of Working Group I to the Fourth Assessment Report of the Intergovernmental Panel on Climate Change Program. Cambridge, UK/New York, USA: Cambridge University Press; 2007, 747-846.

[16] Pal J. S., Giorgi F. and Bi X. (2004) Consistency of recent European summer precipitation trends and extremes with future regional climate projections. Geophysical Research Letters, (31), L13202, doi: 10.1029/2004GL019836. 


\author{
(online) $=$ ISSN $2285-3642$ \\ ISSN-L = 2285 - 3642 \\ Journal of Economic Development, Environment and People \\ Volume 2, Issue 3, 2013 \\ URL: http://jedep.spiruharet.ro \\ e-mail: office jedep@spiruharet.ro
}

[17] Potop V. and Soukup J. (2009) Spatiotemporal characteristics of dryness and drought in the Republic of Moldova. Theor Appl Climatol, (96), 305-318.

[18] Potop V. (2011) Evolution of drought severity and its impact of corn in the Republic of Moldova. TheorAppl Climatol. DOI: 10.1007/s00704-011-0403-2. Vicente-Serrano SM. (2006)

[19] Differences in spatial patterns of drought on different time scales: an analysis of the Iberian Peninsula. Water Resources Management, (20), 37-60. 